\title{
Transformation of Mentality, Culture, and Their Influence on Forming the Creative Socio-Economic Relationship
}

\author{
Urunova $\mathrm{Kh}^{1}$, Pulotova $\mathrm{M}^{2}$ \\ ${ }^{1}$ The candidate of pedagogical sciences, Institute of Economy and Trade of Tajik State University of Commerce \\ ${ }^{2}$ The chief trainer of Institute of Economy and Trade of Tajik State University of Commerce
}

\begin{abstract}
:
The article shows the connection between new creative economical industries with cultural values, thinking and mentality. It is noted that today in the period of fast change of consciousness when the industry of new knowledge is dominating the basic factor of competitiveness is creative characteristic, i.e. to be able to think and make non-standard decisions, ability to realize and show cultural values, peculiarities of thinking and individuality. The importance of creative industry and economy is emphasized in forming new strategies of development of economy and society as well.
\end{abstract}

Key words: mentality, culture, transformation of mentality, transformation of culture, national culture, national peculiarities, creative thinking, creative economy, post-industrial society, creative industry, creative class. 


\section{2nd International Academic Conference on Research in}

\section{SOCIAL SCIENCES}

\section{Introduction.}

The process of economical forming of every nationality has a direct relationship with the culture, way of thinking and mentality of that nation. The branches of economy are actively developing in the postindustrial societies which form new kinds of industries, creative types as well on the basis of the cultural peculiarities. The connection of new creative economical industries with the cultural values and mentality of the nation is evident. It is noted that today in the period of fast change of consciousness when the industry of new knowledge is dominating the basic factor of competitiveness is creative characteristic, i.e. to be able to think and make non-standard decisions, ability to realize and show cultural values, peculiarities of thinking and individuality. From another hand it is the demand of the industry of new knowledge, innovational sectors of the economy of the postindustrial societies where new tendency to transform a spiritual into material is dominating.

\section{Creative cultural industries and forming a creative economy.}

Creative cultural industry is one of the specific branches of the economy which is based on personal and collectivistic creation, talent and cultural peculiarities a creative economy is formed under the creative thinking and the creative and cultural masters play a central role in it. Scientists note fairly that

"...culture is an organic system of ideals and peculiarities of the real, sustainable reproductive system defined by them". ${ }^{1}$

\footnotetext{
${ }^{1}$ Zakirova T.V. Culture as a component of sociocultural reality / T.V. Zakirova// Polythematic network electronic journal of Kuban State Agro University (Scientific journal KubSAU) [Electronic resources]. - Krasnodar: KubSAU, 2014. - № 09 (103). - C. 1052.
} 


\section{2nd International Academic Conference on Research in SOCIAL SCIENCES

The development of the creative cultural industries which form a creative economy is an important aspect of the modern period of the postindustrial society and their instrument is innovation. Today the connection of the development of the society with the development of the creative cultural industry is direct and phenomenal. It takes new forms, new categories of goods and services and new relationship between people appear. Also prerequisites are created for the future development. Here it is necessary to mention Y. Shumpeter who wrote:

"every process of development creates prerequisites for the next development, due to which their forms change and things happen differently"2.

\section{Postindustrial society and forming a creative class in it.}

In fact, modern life is characterized by numerous changes which touched every sphere of social life without exclusion, cultural creative industry as well. These changes are based on the sustainable economic and technological growth, sphere of consumption, civilization of leisure and informational society. Having turned to the concept of the development of the postindustrial society and forming a creative class in it is necessary to note that term "post industrialism" entered the scientific usage at the beginning of the XXth century by A.K.Kumarasvami ${ }^{3}$, and term "postindustrial society" was designed and entered the lexical turnover by an American sociologist Deniel Bell ${ }^{4}$. He has realized researches on the social development and connected forming the society of a new type with forming a creative group of people. Wherein D. Bell refers economy, technology and the system of employment to the social culture which changes dynamically. In his concept Daniel bell puts 5 key components

\footnotetext{
${ }^{2}$ Shumpeter Y.A. Theory of economic development, M.:Progress-1982. 454p. P.156.

${ }^{3}$ Kumarasvami Anand Kentish «Time and Eternity» - 2017. Edit. Russian world -P.101

${ }^{4}$ Bell D. «Coming postindustrial society. Experience of the social forecasting»-. 1973г. «Encyclopedia of an economist» electronic library. www.Grandars.ru/college sociologia,html.
} 


\section{2nd International Academic Conference on Research in}

\section{SOCIAL SCIENCES}

\section{8-30 October, 2020}

MADRID, SPAIN

which can change the thinking of people in the postindustrial society into the direction of new creative industry, the system of decision making on the basis of creative and innovative ideas. (Table 1).

\section{Basic components of postindustrial development according to D.Bell's theory}

\begin{tabular}{|l|l|}
\hline Components & Components elements \\
\hline Sector of economy & $\begin{array}{l}\text { Transition from producing benefits into expansion of service in } \\
\text { the sphere of creative industry as well. }\end{array}$ \\
\hline Structure of business & $\begin{array}{l}\text { Domination of professional and technical classes, forming new } \\
\text { "meritocracy" }\end{array}$ \\
\hline Axial principle of society & Leading role of academic knowledge \\
\hline Future orientation & $\begin{array}{l}\text { Special role of new technology and creative technological } \\
\text { evaluation }\end{array}$ \\
\hline Decision making & Using new creative "Intellectual technology" \\
\hline
\end{tabular}

Source: made by authors on the basis of resource \#4

Besides D. Bell a similar research was done by E. Toffler on learning the postindustrial society and dominating a new type of person with a new type of thinking. In his book "Metamorphoses of authority" (1990) for the first time he noted creating a new intellectual class and introduced term "cognitariat" and said: «a clear physical labor is in the low level and gradually disappears. "Proletariat" with a few number of people busy with a physical labor is a minority and being replaced by "cognitariat". By forming a super symbolic economy a proletariat becomes a cognitariat ${ }^{5}$.

Obviously E. Toffler in "cognitariat" phenomenon includes a new creative class of employers who predominantly are busy with an intellectual labour.

\footnotetext{
${ }^{5}$ Toffler E. «Metamorphoses of authority: knowledge, richness and power at the beginning of the XXth century» -1990. Translation into Russian made by Belokoskova V.V., K.Y. Burmistrova. - M., 2004.// Electronic publication: center of humanitarian technologies. Url:https://gmarket.ru/laborotory/basis 4857
} 


\section{2nd International Academic Conference on Research in}

\section{SOCIAL SCIENCES}

\section{8-30 October, 2020}

MADRID, SPAIN

Another scientist economist P. Druker characterizes a postindustrial society as a society of highly qualified creative employers who in their form a "class of intelletuals" P. Druker notes: ... «knowledge employers will not become a majority in the "society of knowledge", but they already get the leading class. ${ }^{6}$

If to speak about creative class of highly qualified workers who have a high competitiveness in the postindustrial society we can note that in the "economy of knowledge" in the USA about $70 \%$ of all the working power is busy which is shown in the book of a leading Russian specialist on postindustrial society V.L. Inozemtcev "Collapsed civilization". 7

\section{Creative class as a moving factor of the creative economy and creative industry.}

The problems and tasks of forming a creative class as a factor moving the creative economy and creative industry of the modern world are studied by R. Florida in the book "Creative class. People who create the future». In his book he mentions that: «The creative class including the representatives of science, technology, art, Mass media and culture also intellectual employers of different professions covers almost one third of labour resources of the territory of the USA, and in other cities of the country this determinant is higher. Just appearing of this new class and creativity as an economical factor became that process which put start to many secondary side tendencies, - beginning from appearing new branches of economy and business direction till changing that how we live, work and use material resources. $^{8}$

\footnotetext{
${ }^{6}$ Druker P.F. «Era of social transformation», Chapter «Arising», «Society of knowledge». Electronic library «Journal» The Atlantic Monthly 1994. Translation of T. Lapukhina // Electronic publication: Center of humanitarian technology.- 8.12.2006, URL:https://gtmarket.ru/laboratory/expertize/2006/2506.

${ }^{7}$ Inozemtcev V. L. «Collapsed civilization. Available premises and possible consequences of the post economic revolution», Academia Moscow, 1999.- P.724. Electronic resource: Electronic library Litmir URL:https://www. litmir.me/br/ib, date of visit January 15, 2020г).
}

8 Florida R. «Creative class. People who create the future". Electronic on-line library, URL:https://madbook.net/read/22960. Date of visit 15.01.2020). 


\section{2nd International Academic Conference on Research in}

\section{SOCIAL SCIENCES}

MADRID, SPAIN

\section{Conclusion.}

Thus transformation of culture and thinking which we can observe in the global coexistence with society has a direct influence on the socio-economical processes in the postindustrial society. New economic relationship accompanied by "creative thinking" can be born at the result of transformation of culture.

Having analyzed a global character of the creative economy, creative culture and a creative thinking and forming a new creative class which is busy with a creative industry we can possibly say that a new strategy and model of creative industry is being formed which causes the transformation of culture. The strategies of developing creative individual industries undoubtedly has a regional character and in this field a cultural thinking as a peculiarity can be a powerful factor moving the socioeconomic sphere.

\section{References:}

1. Bell D. «Coming postindustrial society. Experience of the social forecasting»-. 1973г. «Encyclopedia of an economist» electronic library. www.Grandars.ru/college sociologia,html. 3. Druker P.F. «Era of social transformation», Chapter «Arising», «Society of knowledge». Electronic library «Journal» The Atlantic Monthly 1994. Translation of T. Lapukhina // Electronic publication: Center of humanitarian technology.- 8.12.2006, URL:https://gtmarket.ru/laboratory/expertize/2006/2506.

3. Zakirova T.V. Culture as a component of sociocultural reality / T.V. Zakirova// Polythematic network electronic journal of Kuban State Agro University (Scientific journal KubSAU) [Electronic resources]. - Krasnodar: KubSAU, 2014. - № 09 (103). - C. 1052.

4. Inozemtcev V. L. «Collapsed civilization. Available premises and possible consequences of the post economic revolution», Academia Moscow, 1999.- P.724. Electronic resource: Electronic library Litmir URL:https://www. litmir.me/br/ib, date of visit January 15, 2020г).

5. Kumarasvami Anand Kentish «Time and Eternity» - 2017. Edit. Russian world -P.101 
6. Toffler E. «Metamorphoses of authority: knowledge, richness and power at the beginning of the XXth century» -1990. Translation into Russian made by Belokoskova V.V., K.Y. Burmistrova. - M., 2004.// Electronic publication: center of humanitarian technologies. Url:https://gmarket.ru/laborotory/basis 4857

7. Florida R. «Creative class. People who create the future". Electronic on-line library, URL:https://madbook.net/read/22960. Date of visit 15.01.2020).

8. Shumpeter Y.A. Theory of economic development, M.:Progress-1982. 454p. P.156. 